\title{
Imagining the 'baffling geography' of age
}

When more time stretches behind than stretches before one, some assessments ... begin to be made. Between what one wished to become and what one has become there is a momentous gap .... Some of us are compelled, around the middle of our lives, to make a study of this baffling geography (James Baldwin, 1967).

Imagination is the mechanism which allows us to engage in a study of our own becoming, across the life cycle, to review the lives we have lived, to contemplate how they might have been different, to evaluate actions we did and did not take, to regard the present as but one possibility of where the path might have led, and ultimately, to construct in our minds' eye a sense of what the future might hold, and aid us as we seek to embrace or avoid the realization of that vision.

In Arthur Frank's list of the key tools of 'narrative equipment,' the last and most important is that of imagination. "Stories", he tells us, have the capacity to arouse people's imaginations; they make the unseen not only visible but compelling" (2010: 41). Here, Frank calls out to the work of Mattingly (1998) who speaks of ' the fragility of events,' the recognitions 'that things might have turned out differently.' Stories create imagination of how the past might have gone differently and the future is open to any possibility... The capacity of stories is to arouse people's imagination concerning how their lives might have been different, and the possibilities that still lie open to them. (Frank 2010:42-43).

In this article, I wish to explore later life as a special moment for the imagination, for persons of all ages. There has been much scholarship on, and community organizing around, reminiscence and life review activities for the elderly. Here, the focus has been individual remembering, or backward (re)imagining 'life as it really happened' - or at least how we retrospectively construct it - and ultimately a coming to terms with that past. In Erik Erikson's life span developmental framework, the identity crisis which characterizes the last stage of life is 'integrity versus despair', where the challenge for the aging person is to appreciate the way in which their lives unfolded as "something that had to be and that, by necessity, permitted of no substitutions" (1963). I have argued elsewhere (author $\mathrm{xxxx}$ ) that the resignation and acceptance which lies at the heart of Erikson's composition would be unnecessary if life review were to appear as a recurring feature throughout the life course: if we were to routinely ask ourselves what is the life we hope to be able to look back on, we would increase the likelihood that our ultimate life review would bring us deeper satisfaction. Randall and McKim (2004) describe growing old as

a process of becoming ... [which] works both retrospectively toward the past and prospectively toward the future. We make sense of our past in light of our expectations for the future, and our anticipations for the future influence our reflections on past experiences..... (p. 242). 
Why, then, do we not devote more attention to this 'curious backward-forward process' (p. 242), imagining our future lives and inviting that vision to help guide us? Perhaps the most obvious answer here is that for many, daily life is all encompassing: responding to the immediate pressures we face does not leave much time for reflections of this nature. Added to this, there are not many spaces in our lives which are conducive to such an activity. Yet its omission depletes the potential of our future lives, living without contemplating a life of other possibilities.

In the following discussion, I will begin by offering an overview of existing scholarship on imagining old age, and then relate this to a longitudinal study I have conducted in East Germany which includes in-depth reflections on the aging process over time. Here I will focus on the experiences of a well known German actress who contemplates the past, present and future of being a woman in a profession which valorizes youth, and the steps she has taken to enhance intergenerational dialogue. From here, I turn to wider debates surrounding what constitutes a 'good life' arguing for a vision which 'bridges the public and private sphere' (Rai xxx) and which contests the highly individualized notion of fulfillment in later life. This argument offers a theoretical framing for the autobiographical experiences discussed in the previous section. I conclude by issuing an ethical call for the re-imagining of late life as a time in which individuals of all ages locate themselves within a wider vision of 'a shared good life'.

\section{Stimulating Imaginations of Future Old Age}

Bornat and Jones (2014) offer several reasons why people often find it hard to imagine their own old age. The first of these is the prevalence of ageism: "If people generally fear and devalue old age, it is perhaps not surprising if they don't want to put themselves in the category 'old person' even in their imagination.' (p. 3) The second reason, not unrelated perhaps to the first, is that our constructions of the aged are built upon a fundamental 'othering' and thus people experience contemplating their own old age as a loss of their 'true self'. Moreover, in our age-segregated society, some people simply don't know any old people. And even when people do try to imagine their own old age, they tend to do so in binary terms; they 'either imagine terrible pessimistic stereotypes of abusive or negligent care in residential homes, or overly optimistic visions of a life of leisure and international travel'. It is notable that while people often worry about 'growing older,' this does not include imagining their own old age.

This lack of imagining 'reinforces ageism, intergenerational conflict and misunderstanding. If you do not really believe that you will ever be old yourself, it is harder to treat the older people you meet as if they are real and complex individuals like yourself' (Bornat and Jones 2014:4). But, there is more at stake than that: to paraphrase Simone de Beauvoir, if we do not know where we are going, we cannot know where we are or where we have been. A sense of our 
future selves not only provides us with a 'blueprint for living' (Andrews 2009) but also an anchoring in the present.

Gubrium and Holstein (2016) frame the question of imagining a future, ageing self within a wider framework of conceptualisations of the self over time. In response to their question : "How shall the future of the ageing self be conceptualized? (p. 124), they offer first two 'time-honored traditions': the first is that of the developmental self, who "unfolds with maturity, and comes to resolution in later life... [a self which is] categorically in place despite significant social, cultural and historical influences." With this, they contrast the "self of the social and cultural sciences and of history. ... the venerable self whose human nature is drawn directly from social order ... the self of this community, that nation, this culture, and that particular historical era." (p. 124). As an alternative to these two reductionist formulations of the self, the authors offer a third possibility, a self which can be viewed as "as a product of practical, situated 'biographical work' ... [which is] open to myriad interpretive possibilities, limited only by the social, cultural and historical circumstances that mediate, but do not determine, biographical work. " p. 125 The research presented in this article can be best understood within this third conceptualisation, that of the situated biographical aging self.

If we do take to imagining our future, aging selves, when and how do we do it? Strategies for encouraging 'imagining futures' have ranged from presenting positive information about old age (Jones 2011), to asking explicit questions about a future self, using specific stimuli such as short films (Phoenix 2014), to methods using drama, poetry and song-writing (Goltz 2008), to eliciting diaries and photographs (Bytheway and Bornat 2010) to letter-writing practices to a future self (Sools 2012) and 'imagined futures essay writing (Weddell, Lyon, Crow and Brett 2012). As someone who has taught a class on aging for many years to final year undergraduates, I have spent considerable time devoted to the task of encouraging students to see themselves in the discussions we have together. On the first day of the class, we have a series of 'warm up exercises' in which we try to trace the collective imaginary which is held in the group: when they hear the term 'old person' who comes to mind? We explore this together in terms of identifiable characteristics (chronological age; gender; race; nationality; historical period; sexual orientation; etc) but also in term of what they are wearing, how they walk, what they do for entertainment, where and how they live, who they socialise with (if anyone), what they do and what they talk about. We then contrast these with descriptions of actual old people they know, and finally this exercise concludes with questions about how they envision their own old age. At the end of the twelve weeks of the course, we repeat the final portion of this exercise, i.e. their imagining of their own old age. What is interesting for me is that having actively dedicated themselves to the topic of how and why people experience aging as they do - and keeping a journal which explicitly addresses connections between their life experiences and the readings, lectures and discussions from the class - students often experience a deepening sense of 
their own life trajectory; studying the 'baffling geography of age' is not for them just an academic exercise.

The single most important resource we have to assist us in imagining our own old age are those who are experienced in the subject. Holstein (2016) makes the case for "the importance of bringing older and younger women together to transform generational differences and expectations" (p. 330). While our society does not afford numerous opportunities for candid intergenerational conversations about age, in fact this is precisely what is needed, so that all of us, regardless of our positioning along the life course, can build bridges between not only ourselves and others but indeed our own older and younger selves.

Another powerful resource is 'the power of the word to move us... to distil what matters to the human spirit" (Bakewell 2013: 11): the ever growing amount of poetry and literature (fiction as well as memoirs) written by the old. One example of this is former US Poet Laureate Donald Hall's (2014) Essays After Eighty. He opens with

Today it is January, mid-month, midday, and mid-New Hampshire. I sit in my blue armchair looking out the window.... Snow started before I woke, and by now it looks to be ten inches... Generation after generation, my family's old people sat at this window to watch the year. There are beds in this house where babies were born, where the same babies died eighty years later (pp. 1-5).

Hall's reader knows they are in the company of a good storyteller, and someone who has lived long and thought a lot about the passage of time. Lines such as 'we divorce for the same reasons we marry' (p. 36) must be read and reread because they hold so much in so few words. By contrast, writer Ceridwen Dovey describes the challenges she faced when she tried to write a book whose protagonist was old. It was, she found, almost impossible not to roll out familiar stereotypes, a grumpy old man, a funky, spirited old woman. Dovey refers to 'the conundrum of who has the authority to write about old age.' She then identifies a growing genre of thought-provoking work by people over seventy-five. Dovey interviews Penelope Lively "among the first true anthropologists of old age, both participant and observer" who describes old age not as a "pallid sort of place," but a time when she experiences "an almost luxurious appreciation of the world." And yet this enhanced appreciation of life is combined with the onset of new challenges for the body; she believes that younger writers often have difficulty portraying characters who are old because they cannot "imagine the less dramatic physical aspects of being old: the constant pain from various forms of arthritis, the slow impairment of sight and hearing, and a "kind of instability," a loss of balance "that would be unnerving if it came on suddenly, but, because it is gradual, you adapt" (Dovey 2015). For Lively, old age holds both potential and challenges for mind, body and soul.

And yet the experience of old age is determined by forces which extend far beyond the individual. Ossewaarde (2014) argues that the emerging 'aged society' demands the (re)imagining not only of individuals, but of the whole of 
society. Citing the work of numerous sociologists, Osserwaarde proclaims that "a new sociological imagination is needed for a new world order" and proceeds to explore "insights regarding the dangers and possibilities that arise when an old order disintegrates and a new one has to be created." (p. 161). Stoetzler and Yuval-Davis (2002) argue that all imaginings are situated: clearly if, and how, one imagines ones own old age has its roots in the wider world. While imagining might happen in the mind of the individual, it is societies which wield the most significant impact upon what is imaginable. Our society, especially in the current moment of demographic changes, focuses on the physical needs of the elderly. While it is of course of urgent necessity that all people are guaranteed a roof over their head, heating, food, and light and have other basic needs fulfilled, these are necessary to, but insufficient for, the nourishment of the imagination. Efforts to visualise our own old age - across the life span - will also help us as a society to reimagine how to meet the needs of the older population.

In the next section, I shall discuss the imaginings of one particular woman, Ruth Reinecke, an East German actress and activist, born in 1955, who participated in a longitudinal study I conducted between 1992 and 2012. Amongst the topics we discussed in this time was her sense of aging, as she looked back over the years we had known one another, and as she looked forward, to her own old age.

\section{Looking backwards, looking forwards}

In 1992, I began a study which was to occupy me for many years to come. My intention was to conduct research on political activists in East Germany who had been critical actors in the bloodless revolution of 1989. In total, I interviewed 40 persons, most of whom were part of the critical opposition movement which had led to these changes. Like the movement itself, they came from a broad spectrum of society: intellectuals, artists, writers, potters, actors and others involved in the theatre, the church, builders and more. (For further discussion of this work, see Andrews 2007). The focus of my study was on their subjective experience of participating in revolutionary change, and the fallout which came in the wake of the dissolution of their country

Twenty years later I was presented with an extraordinary opportunity to reinterview a subset of the original forty participants. ${ }^{1}$ From the start, it was evident to me that part of the follow up interviews must explore participants' experience of the passage of this time, including their sense of aging. I created a methodology which was specifically designed to probe this perspective of the older self looking back on to the self of earlier years. Thus our follow up meetings were framed by a knowledge of an earlier conversation between ourselves, and we began these interviews with a discussion of their experiences of encountering their younger selves.

\footnotetext{
${ }^{1}$ Made possible by a very generous invitation from the Wissenschaftzentrum of Berlin, to be a Visiting Fellow there from 2012-2014.
} 
One of the most elaborate of these conversations was with the actress Ruth Reinecke. She describes her experiences of listening to the recording of our initial interview as encountering "Ruth new and strange" while at the same time a strong sense that "I am not that much different from the person I was before. But I have gathered much more experience." This comment encapsulates a perspective on the self which is marked by both change and continuity, and it is the holding these in balance which constitutes the process of aging. Reinecke's reflections upon her experiences of aging are fundamentally informed by the multiple positionings which she occupies: as a woman who was born shortly after the creation of the country, who grew up under state socialism, and who entered a profession which is notorious for its marginalization of aging women, but which simultaneously offered her some freedoms of which her fellow citizen were deprived, the choices which she has consciously made throughout her life to find alternative pathways to her own aging are informed by these intersecting facets of her identity.

Aging is a topic to which Reinecke has devoted much attention, something which she regards as 'interesting to me [both] in my profession and in my personal life." She describes the world in which she lives as being 'about younger lives' and yet the work of an actress is to 'be a mirror' on life, a difficult task to fulfill if 'the focus is always on the young people.' The world of acting is notoriously difficult for aging women. And yet in the twenty years since I have last seen Reinecke, she has become a very well- known actress in Germany and beyond; one of her roles was that of the Stasi family matriarch in the very popular television series Weissensee. But her own personal success on the screen and stage does not blind her to the general predicament of being an aging woman in a youth-oriented culture. When I ask her to describe her experience of aging over the two decades since we have last met, she tells me: "I was in my forties when I realised that younger people looked at me as an older person and it was like, it was... not a shock but it was a weird experience, because I didn't feel that way." Encountering oneself as an aging person is often brought about through seeing oneself in the eyes of others. In Reinecke's life, this consciousness of aging coincides with the time in which she began to work with students, and with this a change of status: "When I started to teach at a school for acting ... it was a whole new perspective for me. I was perceived by the students in a completely different way because I was the teacher. That is an important point." Professionally, then, Reinecke experienced both the limitations of being an aging woman - how to be a mirror for those who are young - as well as the stature which can accompany certain positions, such as that of teacher. Here she describes a knowledge about aging which she arrives at through her changing role and relationships with others.

Reinecke is of course aware of the bodily changes which accompany age, but that is not what engages her. She refers to 'all this physical changes but I don't have to talk about this, I think this is clear anyway' and then turns her attention elsewhere. 
I learn to accept my new role now, in a new field of life and I learn to look at life differently. I think now I am 56 and in 20 years I will be 76 and what will happen with me in 20 years time? I hope that I can move around and I will be aware of things that I can participate in life. In the world.

Upon turning fifty, Reinecke planned an evening of theatre, "a very personal play about aging." In preparation for this, she read Simone de Beauvoir's Old Age which she describes as "a very important book form me. I read it like a crime novel. I can remember that." The language she employs here is very powerful; not many would bring such intensity to their learning about aging. The metaphor of a crime novel directs the listener to not only the page-turner questions of 'who dunnit' but more fundamentally, to query what transgression has been committed. Ultimately we learn it is a plot which focuses not so much on the crime of getting old (though here deBeauvoir does not hold her punches), but rather on our inability to envision our older selves. Reinecke clearly takes this message to heart, and without hesitation elaborates on her imagined future.

My vision is, I became aware that you cannot avoid aging ... but you can decide how you want to create your life.... I have recognised that the [older] friends I get on very well with live their lives very positively even with difficult illnesses and so on. And I try to be positive; I try to be a good friend, even knowing... Although can I see very clearly the shady side in my life, the painful things like the loss of somebody for example or that you can not participate in parts of the life as before. This is what I clearly experience. And you see, you look at the younger generation and you realise it is not my generation anymore and I don't belong to them. This has really changed me completely.

Reinecke offers a gendered and generational perspective throughout her discussion of aging, which is also peppered with accounts of her mother and her daughter. She has a strong consciousness of an ongoing sense of her own becoming, of her aging. She first experiences herself not as 'old', but rather 'older', in her forties, when she sees how younger people look at her (something which is accentuated when she takes on the new role of teacher.) Turning 50, she sets for herself the personal and professional task of studying and performing aging. This experience of a transforming self is not only written on the body, but is also inscribed in daily practices determined by the state, which emphasise the fixidity of age boundaries and boundedness. Rai describes 'The inclusions and exclusions, entitlements and risks that different groups of citizens experience in performing citizenship" of which the regulation of 'senior identity' is a prototypic example.

Throughout Reinecke's account, she communicates a vision of her future self as one who is in a dynamic web of social relationships, being a good friend to others, being a teacher, being an actress with a responsibility to her audience, being 'knowing' (here drawing on the construction of older people as being persons who have had a certain amount of experience in their lives, and who can bring that to the table as engaged listeners of the woes of others). She is insistent on grounding this vision in the realities which often accompany aging, 
evoking 'illness' 'loss' 'the shady side' in her account. Reinecke does not adopt an attitude of 'agelessness' (Andrews 2009) preferring instead to recognise the importance of age to her evolving self: there is an acknowledgement of a generational distinctiveness -looking at the younger generation, she does not feel that she 'belongs to them.' Reinecke actively imagines her future life as an old person, and the self she envisions is one who is resilient, and engaged with others. As someone whose life has been both literally and figuratively on the public stage - as actor and activist - perhaps this is not altogether surprising.

Reinecke's description of her imagined old age resonates with the paradigm of the relational self developed by Kenneth Gergen (2009). Gergen questions very concept of the self as a self, arguing instead that that "virtually all intelligible action is born, sustained, and/or extinguished within the ongoing process of relationship...We are always already emerging from relationship; we cannot step out of relationship; even in our most private moments we are never alone" (Gergen 2009: xv). In Reinecke's account, one can hear the depth and power of connection that derives from this 'choreography of co-action' (p. 137) in the development of the relational self across the life-span.

\section{Imagination, Age and The Shared Good Life}

Shirin Rai (forthcoming) argues that 'The imaginary of good life ... needs to bridge the public and the private spheres ... and also individual and collective lives - the good life needs to be a shared good life." This assertion has very important implications for the way in which we construct our ideas of the good life in old age, which contrasts with predominant models of 'successful aging' which emphasise the importance of individual agency and control. Ruddick (1999) suggests that there are certain virtues which are particular to old age: "there are virtues salient in the lives of people temporally situated between a lengthening, unalterable past and short future, where loss is predictable but its timing and form is not." (p. 45) Those "whose future is dwindling and who will very likely experience multiple losses and decline" (p. 50) are at the same time presented with challenges which invite them to contemplate the meaning not only of their own lives, but of life in general. As Joan Bakewell comments "With age comes a growing thoughtfulness: what was it all for? What have we made of our lives, what have we known of love, what have we enjoyed of beauty and how do we come to terms with our going? (2013:11). Age can bring with it a propensity to ask of ourselves, what is a life worth living, and how do we measure ourselves against these fundamental yardsticks?

Accepting one's own finitude only highlights the importance of an ending for the narrative arc of a 'good life'. Looking back over the life one has lived, asking oneself the kinds of questions Bakewell poses, might lead one to reimagine what other futures might have been, intermingling questions of 'what if' with those of 'if only.' But such self questioning, looking over what has passed and contemplating the time that still remains, is never wholly or even primarily about the self as a self, but rather points to the conditions of our lives, and the 
relationships which define it. Ruddick constructs virtue as something which is "in the first instance created between and among people; that it is, therefore, inseparable from relationships" (p. 53). She elaborates on this:

The point is really simple. An individual is able to enjoy, remain curious, manage pain, or reflect on death only if she can create the occasions, with others, for doing so. Curiosity itself, or pleasure, or the ability to manage pain comes into being within occasions of relationship.... People together, or the same or different generations, create the encounters with which all parties, each according to their ability, enjoy, sympathize, converse, and demand in ways that express efforts of virtue (p. 53).

The relational model which Ruddick builds resonates with the work of Lamb (2014) who stresses the importance of recognising 'the transcience of the human condition" (p. 42) and the natural limits of our existence. The virtues which can come in old age are not in spite of life's travails, but achieved through confronting them. As Moody argues "Personal meaning is sustained through inner resources permitting continued growth even in the face of loss, pain, and physical decline" (cited in Lamb p.49) Of course the challenges of aging are not uniform, neither for individuals nor globally

Zimmerman and Grebe (2014) have argued that "advanced age can, despite all loss and limitation, [be] understood as a rationally and emotionally evolved and steadying habitus of reserve", an 'epistemic strategy' they call 'senior coolness.' (p. 30). Elaborating on this, they describe coolness as

a habitus of objective self-assertion. It makes it possible to face external demands and indignities with an attitude of self-assurance. Coolness is also a habitus of subjective self-assurance. It makes it possible to face personal indignities, crises of vulnerability and finitude, with an attitude of self-assurance (p. 30).

But people come to know things about the world and themselves not as isolated individuals, but as social beings. In 2015, HelpAge International (2015) determined that elderly people living in the top ten countries of its index measuring the quality of life in old age found live on average 7.3 years longer than those living in the ten nations ranked at the bottom. Inner resources are important, but structural support is critical. Of course one would much prefer to exhibit bold self-assurance rather than despair and neediness, but part of this depends on the wider context. As Blix, Hamran and Norman (2013) demonstrate in their research with Sami elders, "life stories are framed and shaped by dominant public narratives' (p. 271). It is not simply a matter of individual choice how one sees oneself; some realities are more challenging than others, and one must always ask oneself whose old age is being discussed. Holstein (2015) pleads for us to "redefine what it means to live a good and worthy life for us and others like us" (p. 261). Elaborating on this, she argues:

A good life, says Aristotle, is not a scientific problem but a problem calling for practical wisdom, the mean between extremes that we find through 
experience.... We cannot be held accountable for what ... does not meet our considered understanding of what is a good life (Holstein 2015: 104).

\section{Ethical call for the future: Aging and the collective Life}

"Aging is simultaneously a collective human condition and an individualized subjective experience" (Hepworth 2000: 1). A focus on the relational, aging self, engaged in an endeavour to build a shared good life attends to both of these aspects of experience. We grow older in relation to our younger selves. We embody different ages as we travel through life. And we do this with others, with one arm stretched out to those who are older than ourselves, and the other reaching back to those who will follow in our footsteps. What is called for is "our universal participation and solidarity in this most human experience" (Cole 1991: 96).

Simon Biggs (2008) has developed the idea of 'intergenerational intelligence' which refers to

the degree to which one becomes conscious of self as part of a generation, a relative ability to put one's self in the position of other generations and an ability to act with awareness of one's generational circumstances... aging is an intergenerational enterprise which takes place in an intergenerational space. This space is negotiated, and the experiences of each age-group need to inform that negotiation (p. 118).

With generational intelligence, Biggs argues, comes an ability to 'live with a mature imagination' (p. 118). The antithesis to this is a denial of aging, in which the future exists only as a place of impossibility, all that one is not, all that cannot be done, or alternatively an altogether carefree time in which ultimate fulfilment is a matter of individual choice and agency. I have argued elsewhere (2014) that imagination requires both a taking apart and a putting together - synthesis and deconstruction. Imagining old age involves a projection of an earlier self into an altered existence, intermingled with a recognition of the importance of new challenges and possibilities that potentially attend such alterations.

Returning to my interview with actress and activist Ruth Reinecke, we can see that there are some re-imaginings of old age which are highly relational in nature, and built upon a premise of a collective life. Reinecke approaches her aging with intense curiosity ('like a crime novel'), an engagement she applies in her professional life - staging plays which tackle the difficult topic of aging, but also devoting considerable thought to the changing demands for female actors as they age. In her personal life, she has numerous friends who are older than her, and these relationships help her to imagine her own old age as a time when she intends to still 'participate in the world.' For her, the measure of the 'success' of her aging is and will continue to be the flourishing of her relational self, who she is with and in communication with others. Holstein (2010) argues that the acknowledgement of our enduring, relational self 'reshapes our moral commitments' (p.x). The implications of this are, for instance, that 'self-respect is not something that we attain on our own; it is a communal product and, as such, 
an achievement gained through relationships with others.' (p. x). We can see evidence of this attitude in the words of Reinecke, for whom the future is a time which has not only possibility, but also responsibility: to commune with others, to participate, to speak, and to listen.

Using Cornell's phrase 'gift of the future', Squire (2012) refers to the future as 'an other already with us' (p. 69). Here the future is 'not a horizon' but something 'that calls to us, and demands something from us " (p. 69). Imagining our future old age demands something from us; the future calls to us, and we must respond. The puzzle of Baldwin's 'geography of age' is one which forces us to ask of ourselves not only who we are, but who we have become and are still becoming. Regarding our future, our own old age, as 'an other already with us' renders late life as an opportunity for new imaginings, looking forward and backward, to the lives we have lived and still might live. 


\section{Bibliography}

Andrews, M. (2009) “The narrative complexity of successful aging” International Journal of Sociology and Social Policy Special issue on Theorising Aging Studies Vol. 29/1-2: 73-83.

---, (1999) "The seduction of agelessness" Ageing and society 19: 301-318.

Bakewell, J. (2013) “Forward” Halliday, J., ed. Don't Bring Me No Rocking Chair: Poems on Ageing Newcastle: Bloodaxe Books.

Baldwin, James (23 March 1967) “God's Country” New York Review of Books http://www.nybooks.com/articles/1967/03/23/gods-country/ (Last checked 2 November 2017)

Biggs, S. (2008) "Aging in a critical world: The search for generational intelligence" Journal of Aging Studies Vol. 22, No.2: 115-119.

Blix, Bodil Hansen, Torunn Hamran, and Hans Ketil Normann (2013) "Struggles of being and becoming: A dialogical narrative analysis of the life stories of Sami elderly" Journal of Aging Studies 27: 264-275.

Bornat, J. (2014) "Researching the Future with Older People: Experiences with the Oldest Generation" in Jones, R.L. and J. Bornat, eds. Imagining Futures. London: Centre for Policy on Ageing/The Open University.

Bornat, J. and Bytheway, B. (2010) 'Perceptions and presentations of living with everyday risk in later life' British Journal of Social Work 40(4): 1118-11134

Cole, Thomas (1991) "Oedipus ad the Meaning of Aging: Personal Reflections and Historical Perspectives" in Jecker, N., ed. Aging and Ethics: Philosophical Problems in Gerontology Clifton: NJ: Humana Press.

Cornell, D. (2005) “Derrida: The gift of the future” differences 16(3): 68-75.

Dovey, Ceridwen (October 1, 2015) "What Old Age is Really Like" The New Yorker. https://www.newyorker.com/culture/cultural-comment/what-old-age-is-reallylike (Visited 24/10/17)

Gergen, K. (2009) Relational Being: Beyond Self and Community. Oxford: Oxford University Press.

Erikson, Erik (1963) Childhood and Society Harmondsworth: Penguin.

Gubrium, J. and J. Holstein (2016) "Biographical Work and the Future of the Ageing Self” in Gubrium, J., T. Andreassen and P. K. Solvang, eds. (2016) Reimagining the Human Service Relationship New York: Columbia University Press. 
Hepworth, Mike (2000) Stories of Aging Milton Keynes: Open University Press.

Jones, R.L. and J. Bornat, eds. (2014) Imagining Futures. London: Centre for Policy on Ageing/The Open University.

Goltz, D. (2008) Investigating queer future meanings: Destructive perceptions of 'the harder path' Qualitative Inquiry 15(3): 561-586.

Hall, Donald (2014) Essays After Eighty Boston: Houghton Miflin.

HelpAge International (2015) "Global AgeWatch Index 2015: Insight

Report” http://reports.helpage.org/global-agewatch-index-2015-insightreport.pdf (last checked 16.11/17)

Holstein, Martha (2015) Women in Late Life: Critical Perspectives on Gender and Age Rowman \& Littlefield Publishers.

--- (2010) Ethics, Aging and Society: The Critical Turn New York: Springer Publishing Co.

--- (2006) “On Being an Aging Woman' in Calasanti, Toni M. and Kathleen F. Slevin, ed. Age Matters: Realigning Feminist Thinking London: Routledge.

Lamb, Sarah (2014) "Permanent personhood or meaningful decline? Toward a critical anthropology of successful aging" Journal of Aging Studies 29: 41-52

Mattingly, C. 1998 Healing Dramas and Clinical Plots: the Narrative Structure of Experience CUP

Ossewaarde, M. (2014) "Sociological Imagination for the Aged Society" Canadian Journal of Sociology 39(2): 159-180.

Phoenix, C. (2014) 'Erm, I don't know... It's not something that I really think about': Facing the fear in research on ageing. In Jones, R.L. and J. Bornat, eds. Imagining Futures. London: Centre for Policy on Ageing/The Open University.

Rai, Shirin (forthcoming, 2018) "The Good Life and the Bad: Dialectics of Solidarity" Social Politics.

---, (forthcoming 2017) “The dilemmas of performative citizenship" in Dutt. Bishnupriya, Janelle Reinelt and Shrinkhla Sahai, eds. Gendered Citizenship: Manifestations and Performance London: Palgrave Macmillan. 
Randall, W.L. and McKim, A.E. (2004) "Toward a poetics of aging: The links between literature and life" Narrative Inquiry 14(2): 235-260.

Ruddick, Sara (1999). "Virtues and Age" Mother Time: Women, Aging, and Ethics. Walker, Margaret Urban ed. Lanham, MD: Rowman \& Littlefield.

Sools, Anneke (2012) “'To see a world in a grain of sand': Towards FutureOriented What-If Analysis in Narrative Research" Narrative Works: 2(1): 83105.

Squire, Corinne (2012) "Narratives and the Gift of the Future" Narrative Works 2(1): 67-82.

Stoetzler, M. and N. Yuval-Davis (2002) "Standpoint Theory, Situated Knowledge and the Situated Imagination" Feminist Theory 2(20): 315-34.

Weddell, E., Lyon, D., Crow, G. and Morgan Brett, B. (2012) 'Imagining the Future of Work and the Family: What can the aspirations of school-leavers in 1978 and 2010 tell us about the changing nature of society and family life?' Sociology Review 22 (1), pp.2-5

Zimmerman, Harm-Peer and Grebe, Heinrich (2014) "'Senior Coolness'”: Living well as an attitude in later life" Journal of Aging Studies (28): 22-34. 